\title{
Chapter 32
}

\section{Article 39: The Right to Physical and Psychological Recovery of Child Victims}

\author{
Ziba Vaghri, Katherine Covell, and Gerison Lansdown
}

States parties shall take all appropriate measures to promote physical and psychological recovery and social reintegration of a child victim of: any form of neglect, exploitation, or abuse; torture or any other form of cruel, inhuman or degrading treatment or punishment; or armed conflicts. Such recovery and reintegration shall take place in an environment which fosters the health, self-respect and dignity of the child.

\section{What Did Children Say?}

'All youth protection services should be free.' (Western Europe/Other)

'Through UNICEF, an NGO, other people, there to make sure children's rights are respected.' (Western Europe/Other)

'Are the abused children in a safe space?' (Western Europe/Other)

(continued)

\footnotetext{
Z. Vaghri $(\bowtie)$

University of New Brunswick, Saint John, Canada

e-mail: ziba.vaghri@unb.ca

K. Covell

Cape Breton University, Richmon, BC, Canada

e-mail: Katherine_Covell@cbu.ca

G. Lansdown

Carleton University, Ottawa, Canada 
There should be a forum or office which is readily available to channel their issue when they need funding and who are very serious in handling the affairs of child victims. (Africa)

Victims of such nature needs constant frequent counselling for them to return to normalcy. (Africa)

\section{Overview}

Article 39 was drafted to ensure that all children who have experienced any of the harmful treatments noted, as well as armed conflict, have the right to reintegration and recovery, regardless of whether the State Party is in any way responsible for that harm (Tobin and Marshall, 2019, p. 1562). The Committee has interpreted the scope of Article 39 broadly, to include harm as a result of human rights violations, child labour or forced labour, being a refugee, institutionalisation, being a victim of crime, or involved in judicial proceedings. ${ }^{1}$

It is important to understand Article 39 in the context of the Convention's wider protective provisions. It serves to provide remedial interventions when any of those protective rights have been neglected or violated (Tobin and Marshall, 2019, p. 1562). However, neither the drafting history, nor the subsequent work of the Committee, provide any detailed guidance as to the definition of recovery or reintegration. The wording of Article 39 requires promotion rather than attainment of recovery, thus placing a lower burden on States Parties, and arguably a more reasonable one. Nevertheless, States Parties must take all appropriate measures within the scope of their available resources to promote the recovery of a child who has faced any of the listed harms. It therefore requires a broad range of services-medical, legal, educational, vocational, and psychological. Services must be provided in accordance with the Convention in its entirety and must therefore be gender and culturally sensitive, scientifically and medically supported, private and confidential, and non-discriminatory (UN Committee on the Rights of the Child, 2003, para. 37 (c)).

Article 39 was reinforced by the Optional Protocol to the Convention on the Rights of the Child on the sale of children, child prostitution and child pornography and the Optional Protocol to the Convention on the Rights of the Child on the involvement of children in armed conflict. Commitment to these protocols requires States Parties to have a clear focus on rehabilitation, giving children appropriate assistance, by provision of high-quality programmes of recovery and reintegration, which are available and accessible on a non-discriminatory basis.

\footnotetext{
${ }^{1}$ See, for example, concluding observations for Congo (2014a, para. 43 (b)), Russian Federation (2014b, para. 66), Cameroon (2010a, para. 68 (d)), Ecuador (2010b, para. 80), and Afghanistan (2011a, paras. 36-36).
} 


\section{General Principles}

Article 2 Respecting Article 2 obliges States Parties to ensure that all children are offered recovery and rehabilitation services, regardless of age, gender identity, sexual orientation, ethnic or national origin, disability, religion, health, or economic status. ${ }^{2}$ Services must be extended to children who are not nationals of a state, including asylum-seeking, refugee, and migrant children (UN Committee on the Rights of the Child, 2005, para. 12). Recovery programmes of equal quality must be provided for all children who need them, with no discrimination based on parental or child circumstances or characteristics, document status, or location. Some groups of children are more vulnerable to the likelihood of experiencing harms, for example, girls or very young children. The Committee has emphasised the importance of States Parties' ensuring that all such vulnerable children are provided with the appropriate recovery and reintegration services that reflect the nature of harms experienced.

Article 3 When determining the needs of a child who has experienced abuse or harm, and the most appropriate means to address it, the best interests of the child must be a primary consideration. In so doing, a broad range of considerations must be addressed, including the child's views, identity, preservation of family, the necessity for care, protection and safety, and degree of vulnerability (UN Committee on the Rights of the Child, 2013, paras. 53-76).

Article 6 Efforts to promote recovery and reintegration must focus on the child's survival, and on the child's optimal physical, psychological, and social development. To this end, interventions must occur in an environment that fosters the child's health, dignity, and self-respect.

Article 12 States Parties must ensure that children fully understand any options available to them, in terms of their recovery programme, and have their views taken into account and given due weight in decision-making, in accord with their age and maturity.

\footnotetext{
${ }^{2}$ See, for example, the Committee concerns expressed to the Central African Republic regarding the persistent discrimination against girls, and other groups of children including albinos, orphans, children with disabilities, and children accused of witchcraft (2017a, para. 24), and to Qatar where they note there continues to be pervasive discrimination against girls due to the persistence of traditional attitudes (2017b, para. 13). See also Joint General Comment No. 3 (UN Committee on the Protection of the Rights of All Migrant Workers and Members of Their Families and UN Committee on the Rights of the Child, 2017) and the Legislative History (Office of the United Nations High Commissioner for Human Rights and Rädda barnen (Society: Sweden), 2007, pp. 314-334).
} 


\section{Articles Related or Linked to Article 39}

Article 19 reinforces the provisions of Article 4 and specifies the establishment of programmes of support for child maltreatment victims and for those who care for the child, in addition to programmes of prevention.

Article 20 requires that children who are temporarily or permanently deprived of their family environment are provided with special care and assistance as needed to promote recovery and reintegration.

Article 24 provides for the right to the highest attainable standard of health and to access health care services. This provision is key to recovery and reintegration.

Article 25 provides children who have been placed for care, protection, or treatment-including for purposes of rehabilitation-with a right to a periodic review.

Article 27 describes the right of all children to an adequate standard of living, and the responsibilities of their caregivers to secure, within their abilities, living conditions that promote healthy development.

Article 28 provides for the availability and accessibility of education, a crucial component of recovery and fostering health, dignity, and self-respect.

Article 31 describes children's rights to play, recreation, rest, and leisure. The realisation of these rights can be an effective intervention that helps children make sense of their past and facilitates healing.

Articles 32-38 describe the child's right to protection from economic exploitation, illicit and psychotropic drugs, sexual exploitation and abuse, abduction or trafficking, torture, degrading or cruel punishment, and armed conflict. The enjoyment of these rights is fundamental to effective reintegration and recovery, and to the child's capacity to develop to potential.

Article 40 requires that all children who come within the scope of the juvenile justice system must be treated in a manner consistent with 'promoting the child's reintegration and the child's assuming a constructive role in society.'

The Optional Protocol to the Convention on the Rights of the Child on the sale of children, child prostitution and child pornography. In Article 8, this protocol requires States Parties to take appropriate measures to protect the rights and interests of child victims of the practices prohibited under the Protocol, including for their rehabilitation.

The Optional Protocol to the Convention on the Rights of the Child on the involvement of children in armed conflict. Ratifying states are required to give children appropriate assistance, where necessary, for their recovery and social integration. 


\section{Relevant Instruments}

UN Protocol to Prevent, Suppress and Punish Trafficking in Persons Especially Women and Children, supplementing the United Nations Convention against Transnational Organized Crime (2000)

International Convention on the Protection of the Rights of All Migrant Workers and Members of Their Families (1990), which affirms the importance of respecting the rights of children of migrant workers, including those described in Article 39.

\section{Attributes}

\section{Attribute One: Quality and Comprehensiveness of the Programmes of Recovery and Reintegration}

For programmes to be of appropriate quality, they require four components. First, services must be scientifically and medically evidence-based, with mechanisms in place for regular review procedures (UN Committee on the Rights of the Child, 2003, para. 41 (d)). Second, programmes or services must be based on a child's holistic developmental needs. Specific vulnerabilities and needs should be assessed in relation to the Convention and other relevant human rights standards. ${ }^{3}$ Third, children must be afforded opportunities for participation in all aspects of recovery and reintegration programmes, and be provided with information about options available, possible decisions, and their consequences. ${ }^{4}$ Conditions that support and encourage children to express their views are essential (UN Committee on the Rights of the Child, 2009, para. 49). Finally, service and programme providers should be well-qualified professionals with knowledge of children's rights. ${ }^{5}$

Recovery and reintegration programmes should be comprehensive and go beyond treatment for survival to include the child's holistic and optimal development (United Nations High Commissioner for Refugees, 1993). In particular, it is essential that any measures provided take into account the specific age and circumstances of the individual child, as well as the nature of any harm experienced including, for example, medical treatment, physical rehabilitation, family therapy or counselling for trauma (Tobin and Marshall, 2019, pp. 1574-1575). In addition, early responses and treatments are important to mitigate the effects of the violence or neglect experienced (Pinheiro, 2006a), as well as ongoing services and support, such as

\footnotetext{
${ }^{3}$ For example, the Convention Relating to the Status of Refugees would also be considered in assessing the needs of a refugee child (UN Committee on the Rights of the Child, 2013).

${ }^{4}$ See, for example, concluding observations Qatar, (2017b, para. 23 (a)), 2012 Day of General Discussion (2012, paras. 23, 24), General Comment no. 13 (2011b, para. 56).

${ }^{5}$ See, for example, concluding observations for Cameroon (2017c, para. 25 (b)) and Vanuatu (2017d, para. 27 (f)), and General Comment no. 12 (2009, para. 49).
} 
ensuring access to education, to provide a sense of normalcy, structure, and stability that can serve to promote healthy development (UN Committee on the Rights of the Child, 2008, para. 29). Longer-term follow-up services should be provided as necessary in order to promote continued physical and psychological recovery, and to provide protection against potential further maltreatment for all child victims of violence. $^{6}$

\section{Attribute Two: Availability, Accessibility, and Acceptability of the Programmes of Recovery and Reintegration}

States Parties should take all reasonable measures ensure that programmes of recovery and reintegration are available to all child victims of violence, abuse, and exploitation who require them (Nowak, 2005, pp. 36-37) with sufficient resources allocated to ensure that measures taken are adequately funded and sustainable. ${ }^{7}$ Helplines, for example, must be widely available and accessible to maintain effectiveness. ${ }^{8}$

Programmes and services for child victims must also be accessible to them. ${ }^{9}$ Accessibility comprises a number of dimensions (Tobin and Marshall, 2019, p. 1579):

- All relevant services must be affordable to all children requiring help

- Services must be accessible to children in the remotest regions, as well as to children with disabilities

- Children, and where relevant, their families, must be aware of the nature of restorative services and how to access them.

Accordingly, States Parties should undertake information campaigns identifying what constitute abusive and exploitive behaviours, together with provision of

\footnotetext{
${ }^{6}$ See, for example, concluding observations for Republic of Moldovia (2017e, para. 21 (e), 23 (d)), Lebanon (2017f, para. 20 (e)), and Estonia (2017g, para. 29 (b)) and General Comment no. 13 (2011b).

${ }^{7}$ For example, the Committee asked Guinea to allocate the necessary resources to implement a comprehensive policy of recovery and reintegration $(2017 \mathrm{~h}$, para. 30 (a)). See also, concluding observations for Moldovia (2017e, para. 221 (b)), Central African Republic (2017a, para. 12 (a)), General Comment no. 13 (2011b) and General comment No. 19 (2016).

${ }^{8}$ The Committee has noted the lack of resourcing or widespread availability of child Helplines. See, for example, concluding observations for Bhutan (2017i, para. 27), Lebanon (2017f, para. 20 (e)), and Vanuatu (2017d, para. 29 (a)).

${ }^{9}$ For example, the Committee has recommended to Bhutan, Ecuador, and Tajikistan that they ensure children have access to adequate services for recovery and reintegration (2017i, para. 24 (e), 2017 j, para. 25 (f), 2017k, para. 21 (d)). See also the Report of the Independent Expert for the United Nations study on violence against children (Pinheiro, 2006a) and the related World Report on Violence against Children (Pinheiro, 2006b).
} 
information on how to report and to access help and information. ${ }^{10}$ All such information must be provided to children in child-friendly, age-appropriate language, and be distributed to parents and caregivers (UN Committee on the Rights of the Child, 2017c, para. 25 (c)). Information campaigns to promote accessibility are important in conflict and disaster-affected regions, where children are especially vulnerable to physical, emotional, and sexual abuse, exploitation, trafficking, and the worst forms of child labour (UN Committee on the Rights of the Child, 2003). ${ }^{11}$

Finally, services provided under Article 39 must be accessible to every child without discrimination on any of the prohibited grounds in Article 2. Children who have experienced trafficking, sexual exploitation and abuse should always be assumed to be victims and not offenders. ${ }^{12}$ In addition, as specifically referenced in Article 39, and reinforced by the Committee, children involved in any aspect of armed conflict must be considered as victims, and entitled to priority participation in rehabilitation programmes (2005, paras. 56-57). To achieve this end, the adoption of measures to combat racism and xenophobia, and to prevent, reduce, and eliminate attitudes causing or perpetuating discrimination is recommended. ${ }^{13}$ Discriminatory attitudes include misperceptions and negative perceptions of children involved in armed combat, ${ }^{14}$ juvenile justice, or the sex trade, and stigmatisation of unaccompanied or separated migrant or refugee children (UN Committee on the Protection of the Rights of All, Migrant Workers and Members of Their Families and UN Committee on the Rights of the Child, 2017; UN Committee on the Rights of the Child, 2005). It is recommended that States Parties adopt legislative and policy measures to ensure that non-discrimination is an explicit principle in all laws and policies affecting children (UN Committee on the Rights of the Child, 2012).

Programmes must also be acceptable to the child, and States Parties must take all reasonable measures to ensure that they are sensitive to the different needs of different ages or groups of children, according to the harm they have experienced. Particular attention should be made to the specific cultural characteristics of the child's community that may be of relevance in helping them recover, for example,

\footnotetext{
${ }^{10}$ See, for example, concluding observations for Antigua and Barbuda (20171, para. 34), Cameroon (2017c, para. 29), Estonia (2017g, para. 29 (a)), and Vanuatu (2017d, para. 27 (b)).

${ }^{11}$ See also Concluding Observations: Central African Republic (2017a, para. 40 (b), 41 (f)).

${ }^{12}$ For example, as described in the 2012 Day of Discussion (UN Committee on the Rights of the Child, 2012), the criminalization of migration poses a serious challenge to the enjoyment of rights, and punitive approaches to child victims of violence are highly destructive as noted in General Comment no. 13. See also concluding observations for Afghanistan, (2011a, para. 39), in which the Committee points out that child victims of abuse and violence are treated as criminals whereas their abusers enjoy impunity, and Qatar (2017b, para. 23 (d)).

${ }^{13}$ See, for example, concluding observations to Estonia (2017g, para. 29 (a)) and Vanuatu (2017d, para. 27 (d)), General Comment no.6 (2005), and the Joint Comment on Migration (UN Committee on the Protection of the Rights of All Migrant Workers and Members of Their Families and UN Committee on the Rights of the Child, 2017).

${ }^{14}$ See, for example, Concluding Observations on the Optional Protocol: Guinea (2017h, para. 28 (a)).
} 
community-based approaches or traditional healing rituals (Machel, 1996, paras. 174-175).

\section{References}

Machel, G. (1996). Impact of armed conflict on children: Note by the Secretary-General, A/51/306. UN. Accessed November 21, 2020, from http://digitallibrary.un.org/record/223213

Nowak, M. (2005). A commentary on the United Nations convention on the rights of the child, Article 6: The right to life, survival and development. Brill Nijhoff. Accessed September 22, 2020, from https://brill.com/view/title/11606

Pinheiro, P. S. de M. S. (2006a). Report of the independent expert for the United Nations study on violence against children, A/61/299. UN. Accessed November 12, 2020, from http:// digitallibrary.un.org/record/584299

Pinheiro, P. S. de M. S. (2006b). World report on violence against children. UN. Accessed November 22, 2020, from http://digitallibrary.un.org/record/587334

Tobin, J., \& Marshall, C. (2019). Article 39: The right to reintegration and recovery. In J. Tobin (Ed.), The UN convention on the rights of the child: A commentary (pp. 1561-1595). Oxford University Press.

UN Committee on the Protection of the Rights of All Migrant Workers and Members of Their Families \& UN Committee on the Rights of the Child. (2017). Joint General Comment No. 3 (2017) of the Committee on the Protection of the Rights of All Migrant Workers and Members of Their Families and No. 22 (2017) of the Committee on the Rights of the Child on the general principles regarding the human rights of children in the context of international migration, $C M W / C / G C / 3, C R C / C / G C / 22$. UN. Accessed November 6, 2020, from http:// digitallibrary.un.org/record/1323014

UN Committee on the Rights of the Child. (2003). General comment no. 4 (2003) Adolescent health and development in the context of the Convention on the rights of the child, July 1, 2003, $C R C / G C / 2003 / 4$. Accessed October 12, 2020, from https://digitallibrary.un.org/record/503074? $\ln =\mathrm{en}$

UN Committee on the Rights of the Child. (2005). General comment No. 6 (2005) Treatment of unaccompanied and separated children outside their country of origin, September 1, 2005, $C R C / G C / 2005 / 6$. Accessed October 12, 2020, from https://digitallibrary.un.org/record/566055? $\ln =\mathrm{en}$

UN Committee on the Rights of the Child. (2008). Day of general discussion: The right of the child to education in emergency situations. UN. Accessed December 20, 2020, from https://www. ohchr.org/EN/HRBodies/CRC/Pages/DiscussionDays.aspx

UN Committee on the Rights of the Child. (2009). General comment no. 12 (2009) The right of the child to be heard, July 20, 2009, CRC/C/GC/12. Accessed October 12, 2020, from https:// digitallibrary.un.org/record/671444? $\mathrm{ln}=\mathrm{en}$

UN Committee on the Rights of the Child. (2010a). Concluding observations: Cameroon, February 18, 2010, $C R C / C / C M R / C O / 2$. UN. Accessed November 22, 2020, from http://digitallibrary.un. org/record/678065

UN Committee on the Rights of the Child. (2010b). Concluding observations: Ecuador, March 2, 2010, CRC/C/ECU/CO/4. UN. Accessed November 22, 2020, from http://digitallibrary.un. org/record/678501

UN Committee on the Rights of the Child. (2011a). Concluding observations: Afghanistan, April 8, 2011, CRC/C/AFG/CO/1. UN. Accessed November 22, 2020, from http://digitallibrary.un. org/record/702362 
UN Committee on the Rights of the Child. (2011b). General comment No. 13 (2011) The right of the child to freedom from all forms of violence, April 18, 2011, CRC/C/GC/13. Accessed October 12, 2020, from https://digitallibrary.un.org/record/711722? ln =en

UN Committee on the Rights of the Child. (2012). Day of general discussion: The rights of all children in the context of international migration. UN. Accessed December 19, 2020, from https://www.ohchr.org/EN/HRBodies/CRC/Pages/Discussion2012.aspx

UN Committee on the Rights of the Child. (2013). General comment No. 14 (2013) On the right of the child to have his or her best interests taken as a primary consideration (art. 3, para. 1), May 29, 2013, $C R C / C / G C / 14$. Accessed October 12, 2020, from https://digitallibrary.un.org/record/ $778523 ? \ln =\mathrm{en}$

UN Committee on the Rights of the Child. (2014a). Concluding observations: Congo, February 25, 2014, CRC/C/COG/CO/2-4. UN. Accessed November 18, 2020, from http://digitallibrary. un.org/record/778842

UN Committee on the Rights of the Child. (2014b). Concluding observations: Russian Federation, February 25, 2014, CRC/C/RUS/CO/4-5. UN. Accessed November 22, 2020, from http:// digitallibrary.un.org/record/778843

UN Committee on the Rights of the Child. (2016). General comment No. 19 (2016) on public budgeting for the realization of children's rights (art.4), CRC/C/GC/19. UN. Accessed November 12, 2020, from http://digitallibrary.un.org/record/838730

UN Committee on the Rights of the Child. (2017a). Concluding observations: Central African Republic, March 8, 2017, CRC/C/CAF/CO/2. UN. Accessed November 14, 2020, from http:// digitallibrary.un.org/record/1311376

UN Committee on the Rights of the Child. (2017b). Concluding observations: Qatar, June 22, 2017, CRC/C/QAT/CO/3-4. UN. Accessed November 22, 2020, from http://digitallibrary. un.org/record/1311379

UN Committee on the Rights of the Child. (2017c). Concluding observations: Cameroon, July 6, 2017, $C R C / C / C M R / C O / 3-5$. UN. Accessed November 22, 2020, from http://digitallibrary.un. org/record/1311383

UN Committee on the Rights of the Child. (2017d). Concluding observations: Vanuatu, October 25, 2017, CRC/C/VUT/CO/2-4. UN. Accessed November 22, 2020, from http://digitallibrary. un.org/record/1311399

UN Committee on the Rights of the Child. (2017e). Concluding observations: Moldova, October 20, 2017, CRC/C/MDA/CO/4-5. UN. http://digitallibrary.un.org/record/1311387. Accessed November 6, 2020

UN Committee on the Rights of the Child. (2017f). Concluding observations: Lebanon, June 22, 2017, CRC/C/LBN/CO/4-5. UN. Accessed November 6, 2020, from http://digitallibrary.un. org/record/1311380

UN Committee on the Rights of the Child. (2017g). Concluding observations: Estonia, March 8, 2017, CRC/C/EST/CO/2-4. UN. Accessed November 22, 2020, from http://digitallibrary.un. org/record/1311375

UN Committee on the Rights of the Child. (2017h). Concluding observations: Guinea, under article 8 (1) of the Optional Protocol to the Convention on the Rights of the Child on the Involvement of Children in Armed Conflict, October 25, 2017, CRC/C/OPAC/GIN/CO/1. UN. Accessed November 22, 2020, from http://digitallibrary.un.org/record/1311405

UN Committee on the Rights of the Child. (2017i). Concluding observations: Bhutan, July 5, 2017 , $C R C / C / B T N / C O / 3-5$. UN. Accessed November 22, 2020, from http://digitallibrary.un.org/ record/1311382

UN Committee on the Rights of the Child. (2017j). Concluding observations: Ecuador, October 26, 2017, CRC/C/ECU/CO/5-6. UN. Accessed November 14, 2020, from http://digitallibrary. un.org/record/1311757 
UN Committee on the Rights of the Child. (2017k). Concluding observations: Tajikistan, October 25, 2017, CRC/C/TJK/CO/3-5. UN. Accessed November 7, 2020, from http://digitallibrary.un. org/record/1311398

UN Committee on the Rights of the Child. (20171). Concluding observations: Antigua and Barbuda, June 30, 2017, CRC/C/ATG/CO/2-4. UN. Accessed November 18, 2020, from http://digitallibrary.un.org/record/1311381

United Nations High Commissioner for Refugees. (1993). UNHCR policy on refugee children. Accessed November 22, 2020, from https://www.unhcr.org/excom/scip/3ae68ccc4/unhcrpolicy-refugee-children.html

United Nations Office of the High Commissioner for Human Rights \& Rädda Barnen (Society: Sweden). (2007). Legislative history of the convention on the rights of the child. United Nations. https://digitallibrary.un.org/record/602462? $\ln =\mathrm{en}$

Open Access This chapter is licensed under the terms of the Creative Commons Attribution 4.0 International License (http://creativecommons.org/licenses/by/4.0/), which permits use, sharing, adaptation, distribution and reproduction in any medium or format, as long as you give appropriate credit to the original author(s) and the source, provide a link to the Creative Commons license and indicate if changes were made.

The images or other third party material in this chapter are included in the chapter's Creative Commons license, unless indicated otherwise in a credit line to the material. If material is not included in the chapter's Creative Commons license and your intended use is not permitted by statutory regulation or exceeds the permitted use, you will need to obtain permission directly from the copyright holder.

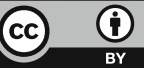

